\title{
Control of honey mesquite with herbicides: influence of plant height
}

\author{
P.W. JACOBY, C.H. MEADORS, AND R.J. ANSLEY
}

\begin{abstract}
Stands of honey mesquite (Prosopis glandulasa var. glandulosa) were treated with aerially applied herbicides at 16 locations in weatern and northwestern Texas over an 8-year period to determine infuence of plant height on herbleide efficacy. Plant height was not found to significantly $(P<0.05)$ infuence effectiveneas of a particular herbicide, but taller plants were found consiatently to be more resistant. No basis was found for delayins control of honey mesquite with herbleides until plants reach a particular height.
\end{abstract}

Key Worda: clopyralid, triclopyr, 2,4,5-T, picloram, plant reaiatance

Honey mesquite (Prosopis glandulosa var. glandulosa) has maintained essentially the same distribution and density on 22 million ha of Texas rangeland for over 4 decades despite substantial control efforts (Rechenthin et al. 1964). Although mesquite has a proven ability to reproduce in large numbers from seed, such events are mainly episodic, occurring after periods of drought and overgrazing have weakened the competitive ability of native grasses (Fisher et al. 1959, Bovey and Meyer 1981). Reestablishment of mesquite following control by aerial application of herbicides or mechanical top removal may relate more directly to the degree of plant mortality achieved with the treatment than any other factor. Honey mesquite vigorously resprouts from dormant buds at the stem base when apical dominance is broken (Fisher et al. 1946).

The herbicide 2,4,5-T [(2,4,5-trichlorophenoxyl)acetic acid], which was widely used for mesquite control until its production and sale were discontinued in the early 1980's, was highly variable in producing mortality of honey mesquite (Meyer et al. 1972). Much of this variability in control has been attributed to environmental factors; however, growth type and plant height have been suggested as variables which may influence mortality (Fisher et al. 1956, Dahl et al. 1971, Meyer et al. 1972). After considerable observation, Fisher et al. $(1956,1959)$ concluded that regrowth must reach a height of $1.5 \mathrm{~m}$ or more to provide sufficient foliage to intercept and translocate enough herbicide to produce complete plant mortality of honey mesquite. These reports led subsequently to the recommendation in Texas that aerial spraying on mesquite be delayed until plants were at least $1.5 \mathrm{~m}$ tall and 4 to 6 years old

\footnotetext{
Authors are professor, research associate, and post-doctoral research associate, Texas A\&M University Agricultural Research and Extension Center, P.O. Box 1658, Vernon, Texis 76384.

Research was funded in part by: University Lands-Surface Interests, Univ. Texas System, Midland; E. Paul and Helen Buck Wagagoner Foundation, Vernon; and Brush Control and Range Improvement Association, Albany. Herbicides were provided by Dow Chemical, USA, and aerial application was furniahod by: Hardcastle A\&-Air, Inc., Vernon; Bruton Aerial Spraying, Inc., Garden City, HaW Flyine Serv., Midland; and Lynn Culp, Breckenridge. Detailed soil clastification and mapping was provided by the Soil Conservation Service, USDA.

This article is published with the approval of the Director, Texas Agricultural

Experiment Station as technical article TA-23924.

Menuscript acopted 17 May 1989.
}

with dense foliage (Hoffman 1975).

We found little published data to support the concept that honey mesquite can be more effectively reduced or killed as it attains increased age or height. Therefore, our objective in this study was to determine the influence of plant height on degree of mesquite stand mortality in order to test our hypothesis that height of plants has little, if any, influence on degree of mortality following aerial application of herbicides.

\section{Materials and Methods}

Herbicides were applied to honey mesquite at 16 locations in western and northwestern Texas from 1797 to 1983. Herbicides included 2,4,5-T, triclopyr $\{[(3,5,6-$ trichloro-2-pyridinyl)oxy]acetic acid\}, clopyralid (3,6-dichloro-2-pyridinecarboxylic acid) and equal part [acid equivalent (ae)] combinations of each with picloram (4-amino-3,5,6-trichloro-2-pyridinecarboxylic acid). All comparisons for this study were made at the $0.6 \mathrm{~kg} \mathrm{ha}^{-1}$ rate of application in a total volume of 9 or $18 \mathrm{~L} \mathrm{ha}^{-1}$ of a diesel oil:water emulsion [1:6 (v:v)]. Treatments were applied by fixed-wing aircraft to two or three $2-4$ ha plots in a randomized complete block design. Some herbicide treatments were omitted from specific locations and these missing values were addressed in the analyses.

Evaluations were conducted after 3 growing seasons to allow sufficient time for herbicide activity to be completed and resprouting to occur. Individual plants (200 to 300 per plot) were examined for presence of live stem or leaf tissue and assigned to one of 3 height classes: $<1 \mathrm{~m}=$ Class I; 1 to $2 \mathrm{~m}=$ Class II; and $>2 \mathrm{~m}=$ Class III.

Data were processed by analysis of variance using percent plant mortality in each height class and plot as a data point. Percentage data were transformed $(\arcsin \sqrt{x}$ ) prior to analysis. Level of significance for mean separation was $<0.05$ and significantly differing means were separated by Tukey's procedure (Steel and Torrie 1980). Herbicides were compared within and among locations, and mortalities evaluated by height class within and among locations and herbicides. Significant interactions between herbicides, height classes and locations were not found and these sources of variation were incorporated into the general error term for the analyses (Steel and Torrie 1980).

Treatment locations incorporated a broad geographical region typical of rangeland on which honey mesquite poses a major management problem to landowners (Table 1). Although treatments were applied during the recommended $\mathbf{4 0}$ to 90 day period following budbreak (Fisher et al. 1959), differences in growth conditions among locations and years of study provide sources of error that are difficult to isolate and partition for statistical analysis without a large number of observations. 
Table 1. Dewerpdion of experimental locations where sertal applications of herbicides were made to control honey meagutte in wextern and northweatern

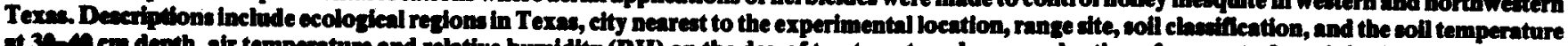
at 30-49 cen depth, ah temperature and relative humidity (RF) on the day of treatment, and a general rating of amoumt of precipitation recelved from January to the treatment date [normal $=(N)$, above normal $=(+)$, below normal $=(-)$.

\begin{tabular}{|c|c|c|c|c|c|c|c|c|}
\hline \multirow{2}{*}{$\begin{array}{c}\text { Ecological } \\
\text { Region }\end{array}$} & \multirow[b]{2}{*}{ Location } & \multirow{2}{*}{$\begin{array}{c}\text { Treatment } \\
\text { Date }\end{array}$} & \multirow{2}{*}{$\begin{array}{l}\text { Range } \\
\text { Site }\end{array}$} & \multirow{2}{*}{$\begin{array}{c}\text { Soil } \\
\text { Classification }\end{array}$} & \multicolumn{2}{|c|}{ Temp } & \multirow[b]{2}{*}{ R.H. } & \multirow[b]{2}{*}{ Precipitation } \\
\hline & & & & & Soil & Air & & \\
\hline $\begin{array}{l}\text { Limestone } \\
\text { Prairie } \\
\text { Edwards } \\
\text { Plateau }\end{array}$ & $\begin{array}{l}\text { Vernon } \\
\text { Vernon } \\
\text { Vernon } \\
\text { Vernon } \\
\text { Vernon } \\
\text { Vernon } \\
\text { Guthrie } \\
\text { Baird } \\
\text { Albany } \\
\text { Barnhart } \\
\text { Barnhart } \\
\text { Barnhart } \\
\text { Ozona } \\
\text { Crane } \\
\text { Post } \\
\text { Dumas }\end{array}$ & $\begin{array}{l}20 \text { June } 1977 \\
6 \text { July } 1979 \\
19 \text { June } 1981 \\
7 \text { July } 1981 \\
25 \text { June } 1982 \\
14 \text { July } 1982 \\
7 \text { June } 1983 \\
29 \text { June } 1979 \\
27 \text { June } 1981 \\
27 \text { June } 1979 \\
26 \text { June } 1980 \\
\text { 15 June } 1983 \\
8 \text { July } 1982 \\
\text { 26 May } 1977 \\
\text { 25 May } 1983 \\
7 \text { July } 1983\end{array}$ & $\begin{array}{l}\text { clay loam } \\
\text { clay loam } \\
\text { clay loam } \\
\text { clay loam } \\
\text { clay loam } \\
\text { clay loam } \\
\text { clay loam } \\
\text { clay loam } \\
\text { clay loam } \\
\text { clay loam } \\
\text { clay loam } \\
\text { clay loam } \\
\text { clay loam } \\
\text { sandy } \\
\text { deep hardland } \\
\text { shallow upland }\end{array}$ & $\begin{array}{l}\text { Typic Paleustolls } \\
\text { Typic Paleustolls } \\
\text { Typic Paleustolls } \\
\text { Typic Paleustolls } \\
\text { Typic Paleustolls } \\
\text { Typic Paleustolls } \\
\text { Typic Paleustolls } \\
\text { Typic Paleustolls } \\
\text { Typic Paleustolls } \\
\text { Petrocalcic Calciustolls } \\
\text { Petrocalcic Calciustolls } \\
\text { Petrocalcic Calciustolls } \\
\text { Petrocalcic Calciustolls } \\
\text { Ustalfic Haplargids } \\
\text { Aridic Paleustolls } \\
\text { Calciorthidic Paleustols }\end{array}$ & $\begin{array}{l}\circ \mathrm{C} \\
30 \\
27 \\
26 \\
27 \\
26 \\
26 \\
19 \\
27 \\
27 \\
27 \\
28 \\
22 \\
26 \\
28 \\
22 \\
25\end{array}$ & $\begin{array}{c}\circ \mathrm{C} \\
26-28 \\
23-33 \\
21-26 \\
21-29 \\
19-21 \\
18-27 \\
10-14 \\
24-27 \\
21-29 \\
19-22 \\
21-30 \\
26-29 \\
23-27 \\
22-29 \\
16-22 \\
20-33\end{array}$ & $\begin{array}{c}\% \\
79-69 \\
96-62 \\
99-76 \\
94-66 \\
96-86 \\
99-75 \\
94-84 \\
74-71 \\
74-67 \\
90-75 \\
72-62 \\
66-62 \\
80-76 \\
84-50 \\
96-72 \\
72-65\end{array}$ & $\begin{array}{l}\mathbf{N} \\
\mathbf{N} \\
+ \\
+ \\
\mathbf{N} \\
\mathbf{N} \\
+ \\
\mathbf{N} \\
+ \\
\mathbf{N} \\
- \\
- \\
+ \\
+ \\
- \\
-\end{array}$ \\
\hline
\end{tabular}

\section{Results}

For most locations, mortality of honey mesquite within a herbicide treatment either remained constant or decreased with increasing plant height (Table 2). Exceptions were found at Albany and Ozona with the combination of 2,4,5-T and picloram, at Dumas with triclopyr, and at Ozona with the combination of clopyralid and picloram. These data, while failing to establish any clear patterns of plant susceptibility by height, illustrate why confusion may exist regarding this relationship. Considering the data for 2,4,5-T alone, there appears to be little basis for suggesting that taller plants are more susceptible than shorter ones.

A more consistent trend was apparent when data were pooled across locations for the individual herbicide treatments (Table 3). Even though mortality of honey mesquite consistently decreased with increasing plant height, rarely were the differences significant. Degree of stand mortality was more consistent for clopyralid or its mixture with picloram than found with the other herbicides. Being more efficacious against honey mesquite than the other herbicides, clopyralid consistently produced high mortality; whereas $2,4,5-\mathrm{T}$ and triclopyr, applied alone or in combination with picloram, produced practically no mortality on occasion. Picloram reduced the variation in mortality achieved by either $2,4,5-\mathrm{T}$ or triclopyr alone by increasing efficacy of those herbicides. However, picloram mixed with clopyralid increased variability over clopyralid alone and was less efficacious against small to medium height plants.

Comparing herbicides across all locations and height classes reiterates the improved efficacy of clopyralid over other herbicides for controlling honey mesquite (Table 3). Relative effectiveness of these herbicides is similar to those reported in other studies (Bovey and Mayeux 1980, Bovey et al. 1981, Jacoby et al. 1981, Jacoby and Meadors 1983).

Table 2. Percentage mortality of honey mesquite at each location according to herbielde and height clase. Miading vahues are decignated by dashed lines.

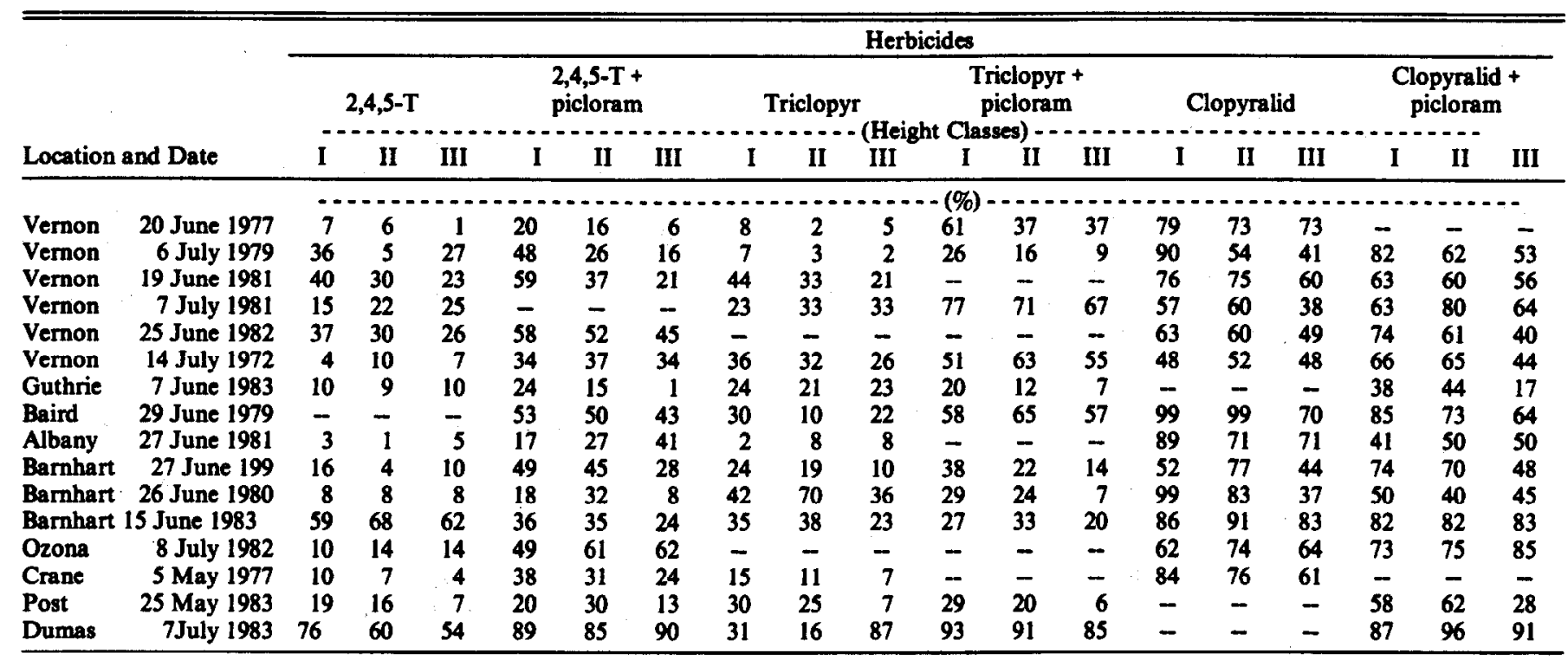


Table 3. Mean mortality of honey mesquite summarized for all locations by herbicides or equal part mixtures applied at $0.6 \mathrm{~kg} \mathrm{ha}^{-1}$ and evaluated 3 post-trentment.

\begin{tabular}{|c|c|c|c|c|}
\hline \multirow[b]{2}{*}{ Herbicide } & \multicolumn{3}{|c|}{ Height Class } & \multirow{2}{*}{$\begin{array}{l}\begin{array}{l}\text { Pooled } \\
\text { Height }\end{array} \\
\bar{x}\end{array}$} \\
\hline & I & II & III & \\
\hline & & $-\%$ & & (\%) \\
\hline $\begin{array}{l}\text { 2,4,5-T } \\
\text { 2,4,5-T + Picloram } \\
\text { Triclopyr } \\
\text { Triclopyr + Picloram } \\
\text { Clopyralid } \\
\text { Clopyralid + Picloram }\end{array}$ & $\begin{array}{l}25.5 \mathrm{a}^{1} \\
40.4 \mathrm{a} \\
25.7 \mathrm{a} \\
44.7 \mathrm{a} \\
76.4 \mathrm{a} \\
67.9 \mathrm{a}\end{array}$ & $\begin{array}{l}24.4 \mathrm{a} \\
38.3 \mathrm{a} \\
23.1 \mathrm{a} \\
40.6 \mathrm{a} \\
74.0 \mathrm{a} \\
66.8 \mathrm{a}\end{array}$ & $\begin{array}{l}21.5 \mathrm{a} \\
29.9 \mathrm{~b} \\
21.5 \mathrm{a} \\
31.9 \mathrm{~b} \\
58.6 \mathrm{~b} \\
56.7 \mathrm{~b}\end{array}$ & $\begin{array}{l}23.1 \mathrm{z}^{2} \\
36.2 \mathrm{y} \\
23.4 \mathrm{z} \\
31.9 \mathrm{y} \\
69.7 \mathrm{x} \\
63.8 \mathrm{x}\end{array}$ \\
\hline$\overline{\text { Pooled Herbicide }(\bar{x})}$ & $44.8 \mathrm{a}$ & $42.5 \mathrm{a}$ & $35.3 \mathrm{~b}$ & \\
\hline
\end{tabular}

IMeans within a row followed by the same letter $(a, b)$ are not significantly different at the 0.05 level of probability.

2Means within a column followed by the same letter $(x, y, z)$ are not significantly different at the 0.05 level of probability.

Pooling mortality data by height class across all locations indicates a stronger difference than shown in previous comparisons (Table 3). Height of honey mesquite plants in this grouping indicates plants become more resistant to herbicides with increasing height, but efficacy was not significantly reduced until plant height exceeded $2 \mathrm{~m}$.

Lack of significant interactions indicates that differences in mortality among herbicides, height classes, or locations were not strongly influenced by one another but rather, each variable responded independently. Therefore, the influence of height would be equally applicable to all herbicides and locations.

\section{Discuscion}

These data, which are based on observed responses of more than 40 thousand individual honey mesquite plants to aerially applied herbicides, presents a sound basis for rejecting the concept that herbicidal treatments should be delayed until plants reach a particular height. In contrast, these data indicate that honey mesquite may become increasingly resistant to herbicidal control measures as they become taller.

Our data fail to explain why taller plants may be less susceptible to herbicides than shorter plants, leaving the reasons open to speculation. Intuitively, several possibilities can be enumerated. Shorter plants, after absorbing herbicide, have less distance to translocate the material to the basal bud zone. These shorter stems may not absorb or metabolize as much herbicide during translocation as would taller stems. Younger stem tissue, prior to the development of thick bark, may actively absorb herbicide spray and contribute to total herbicide uptake. Taller plants may also develop sufficient foliage to provide a shielding effect on a portion of the canopy, especially on the lower or leeward side of the tree during treatment. Taller plants may be deeper rooted, responding more slowly to soil warming, a factor linked to herbicide susceptibility.

Regardless of the causative factors, implications of this study fail to support the decision for a landowner to delay treatment of honey mesquite with aerially applied herbicides because of plant height. Delaying treatment provides mesquite additional time to grow and become more resistant, to compete with forage plants and reduce production of rangeland, and to interfere with livestock handling.

This study also indicates that risk avoidance can be accomplished by selection of a herbicide which is capable of producing high efficacy with consistency. Current recommendations for retreating mesquite every 5 to 7 years are based on the low efficacy achieved with 2,4,5-T (Whitson and Scifres 1981, Van Tassel and Conner 1986). While this recommendation is still valid for triclopyr, more effective products such as clopyralid create new possibilities through higher degree of stand mortality. It has been noted that forage response associated with mesquite control may be lost 1 to 3 years after treatment unless a high degree of stand mortality is achieved (Dahl et al. 1978, Torell and McDaniel 1986). Achieving high levels of plant mortality would appear to be more advantageous than merely removing top growth, considering current prices for herbicides.

\section{Summary}

Height of individual honey mesquite plants was evaluated as influence on the effectiveness of aerially applied herbicides. Plant height was not found to influence the efficacy of any particular herbicide, although taller plants generally showed greater resistance. There does not appear to be any rationale for delaying herbicidal treatment until honey mesquite plants reach a specific height.

\section{Literature Cited}

Bovey, R.W., and H.S. Mayeux. 19se. Effectiveness and distribution of 2,4,5-T, triclopyr, picloram, and 3,6-dichloropicolinic acid in honey mesquite (Prosopis glandulosa var. juliflora). Weed Sci. 28:666-670.

BoveJ, R.W., and R.E. Mejer. 1981. The response of honey mesquite to herbicides. Texas Agr. Exp. Sta. Bull. 1363.

Bovey, R.W., R.E. Meyer, and J.R. Bauer. 1981. Potential herbicides for brush control. J. Range Manage. 34:144-148.

Dahl, B.E., R.E. Sowebee, J.P. Goen, and C.S. Brumley. 1978. Will mesquite control with 2,4,5-T enhance grass production? J. Range Manage. 31:129-131.

Dahl, B.I., R.B. Wadley, M.R. George, and J.L. Talbot. 1971. Influence of site on mesquite mortality from 2,4,5-T. J. Range Manage. 24:210-215.

Fishor, C.E., J.L. Fulte, and H. Hopp. 1946. Factors affecting action of oils and water soluable chemicals in mesquite eradication. Ecol. Monogr. 16:10-126.

Fither, C.E., C.H. Meadora, and R. Behrens. 1956. Some factors that influence the effectiveness of 2,4,5-trichlorophenoxyacetic acid in killing mesquite. Weeds 4:139-147.

Fiaher, C.E., C.H. Meadora, R. Behrem, E.D. Robien, P.T. Marion, and H.L. Morton. 1959. Control of mesquite on grazing lands. Texas Agr. Exp. Sta. Bull. 935.

Hofiman, G.0. 1975. Control and management of mesquite on rangeland. Texas Agr. Ext. Serv. Misc. Pub. 386.

Jacoby, P.W., and C.H. Meadors. 1983. Triclopyr for control of honey mesquite (Prosopis juliflora var. glandulosa). Weed Sci. 31:681-685.

Jacoby, P.W., C.H. Meadors, and M.A. Foster. 1981. Control of honey mesquite (Prosopis juliflora var. glandulosa) with 3,6-dichloro-picolinic acid. Weed Sci. 29:376-378.

Meyer, R.E., R.W. Bovey, W.T. McKelvy, and T.E. Riley. 1972. Influence of plant growth stage and environmental factors on the response of honey mesquite to herbicides. USDA, Agr. Res. Serv., and Texas Agr. Exp. Sta. Bull. 1127.

Rechenthin, C.A., H.M. Bell, R.J. Pederson, and D.B. Polk. 1964. Grassland restoration. II. Brush Control. USDA, SCS, Temple, Texas.

Steel, R.G.D., and J.H. Torrie. 1980. Principles and procedures of statistics -a biometrical approach. McGraw-Hill Book Co., New York.

Torell, L.A., and K.C. McDaniel. 1986. Optimal timing of investments to control honey mesquite. J. Range Manage. 39:378-382.

Van Tasell, L.W., and J.R. Conner. 1986. An economic analysis of brush control practices and grazing systems in the Rolling Plains of Texas. Texas Agr. Exp. Sta. Misc. Pub. 1619.

Whitson, R.E., and C.J. Sclfres. 1981. Economic comparison of honey mesquite control methods with special reference to the Texas Rolling Plains. J. Range Manage. 34:415-420. 